\title{
The Use of Blockchain Technology in The Islamic Financial Industry During The Covid-19 Pandemic: Maslahah Perspective
}

Azlin Alisa Ahmad, Mat Noor Mat Zain, Noor Diyana Amanina Zakaria

To Link this Article: http://dx.doi.org/10.6007/IJARAFMS/v11-i3/10969 DOI:10.6007/IJARAFMS /v11-i3/10969

Received: 19 June 2021, Revised: 23 July 2021, Accepted: 10 August 2021

Published Online: 28 August 2021

In-Text Citation: (Ahmad et al., 2021)

To Cite this Article: Ahmad, A. A., Zain, M. N. M., \& Zakaria, N. D. A. (2021). The Use of Blockchain Technology in The Islamic Financial Industry During The Covid-19 Pandemic: Maslahah Perspective. International Journal of Academic Research in Accounting Finance and Management Sciences, 11(3), 315-326.

Copyright: (C) 2021 The Author(s)

Published by Human Resource Management Academic Research Society (www.hrmars.com)

This article is published under the Creative Commons Attribution (CC BY 4.0) license. Anyone may reproduce, distribute, translate and create derivative works of this article (for both commercial and non-commercial purposes), subject to full attribution to the original publication and authors. The full terms of this license may be seen at: http://creativecommons.org/licences/by/4.0/legalcode

Vol. 11, No. 3, 2021, Pg. 315 - 326

Full Terms \& Conditions of access and use can be found at http://hrmars.com/index.php/pages/detail/publication-ethics 


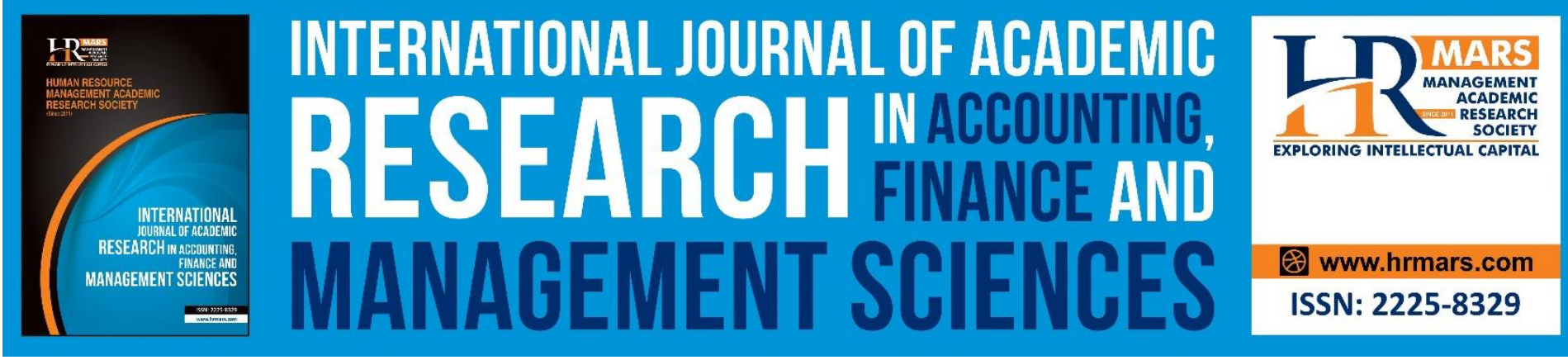

\title{
The Use of Blockchain Technology in The Islamic Financial Industry During The Covid-19 Pandemic: Maslahah Perspective
}

\author{
Azlin Alisa Ahmad, Mat Noor Mat Zain, Noor Diyana Amanina \\ Zakaria
}

Research Centre for Shariah, Faculty of Islamic Studies, Universiti Kebangsaan Malaysia.

\begin{abstract}
Spread of the Covid-19 pandemic has swept across Malaysia causing severe disruption and malfunction of the economic sector. Trade agreements between two or more parties usually carried out in a face-to-face manner is not permitted during the Movement Control Order (MCO). However, blockchain technology has the capability to help coordinate and seal agreements safely without the need for face-to-face meetings. Trade agreements can use the Ethereum smart contract, which is aided by blockchain technology. This qualitative study, which applied the content analysis method, aimed to identify the importance of blockchain technology to the financial industry throughout the Covid-19 pandemic. Findings show that blockchain plays a significant role in the Islamic financial sector because it can be applied effectively during the pandemic; in addition to the benefits accrued in the form of the preservation of life and property. Each transaction is permanently recorded in the blockchain and it is difficult to delete or destroy it. It is also significant because it can be widely used for managing agreements between parties and implementing paperless transactions in the future.
\end{abstract}

Keywords: Blockchain Technology, Islamic Financial Industry, Covid-19, Maslahah

\section{Introduction}

The Covid-19 pandemic has spread rampantly on a global scale, making it very difficult to control, including in Malaysia. This pandemic has caused the economic sector to plummet due to the Movement Control Order (MCO), which came into force in March 2020 (Yusainy, 2021). Daily social activities, including economic activities, have been restricted in order to break the pandemic chain. Moreover, the Pioneer Index (PI) had fallen to $-5.5 \%$ in April 2020 because companies were struggling to maintain their businesses and keep them afloat (Shahir, 2020). The Movement Control Order (MCO) had caused the banking sector to experience major problems due to the moratorium declared on loan repayments under the government's economic stimulus plan (A Kadir, 2020). In addition, the Covid-19 pandemic had affected the economic sector, including big and small companies, in terms of the relations between the 
MANAGEMENT SCIENCES

Vol. 11, No. 3, 2021, E-ISSN: 2225-8329 @ 2021 HRMARS

customer and supplier whereby restrictions were placed on the communication infrastructure between them (Anon, 2020).

Ever since the MCO was introduced, the government has tightened the Standard Operation Procedures (SOP), such as limitations to social activities amongst members of the society by introducing the "work from home" culture. Employers or companies who transgress the "work from home" order can face action or a compound amounting to RM50,000.00 for companies and RM10,000.00 for employees (Amir, 2021). In order to solve this issue that mainly affects the economic sector, most industries have realised the importance of digital transformation. The use of technology is important for maintaining their industry, especially their communication system during the Covid-19 pandemic (Anon, 2020). At the same time, technology can stimulate employees' productivity when "working from home". Blockchain has a great potential to play a major role in the digital transformation platform during the Covid-19 pandemic. Blockchain has the capability to track private data and protect it from cyber criminals by using the decentralised tracking system (Marbouh et al., 2020). The smart contract application in the blockchain can also verify each stipulated condition and agreement automatically without involving a third party. Each transaction recorded in the blockchain is encrypted and sent to each node in the channel for verification and is attached together with other blocks (Abouzid, 2020).

The use of blockchain as an innovative technology not only safeguards security but it is also efficient in processing each transaction. Blockchain can solve any scalability issues based on the use of the decentralisation application. The decentralisation concept can provide a node when the system is required at any time (Lahiri, Mandal, Banerjee, \& Biswas, 2021). Although blockchain technology has advantages in protecting the economic sector, especially during the Covid-19 pandemic, the reception and response towards blockchain technology from society is still at a worrying and cautious level (Bashah, 2017). Based on the ethics and safeguarding of societal benefits according to Syarak, the effects of implementing blockchain technology in the economic sector is measured using maqasid al-shariah. The maqasid alshariah measure not only safeguards societal benefits but it also aims to determine the intentions of Syariah from several aspects, which will be discussed in this study. Maqasid alshariah plays an important role as a measure based on major resources or references in Islam, namely the al-Quran and Sunnah, as the basis in the Syariah framework.

\section{Blockchain as An Innovation in Financial Technology}

Blockchain is a technology that allows various types of transactions to be implemented based on the decentralisation concept. Any transaction that uses blockchain technology only involves two parties without involving a third party (intermediary) or authority. A token known as the crypto currency is used in blockchain technology as a medium of exchange for maintaining the decentralisation concept. Each transaction is liable to a transaction charge or 'gas fee'. Hash cryptography is used as a code for allowing more than one document to be kept in one block. Following is a sketch depicting the functions of hash cryptography. 
Diagram I Sketch Depicting Recorded Transactions that are changed in the Hash Cryptography Code

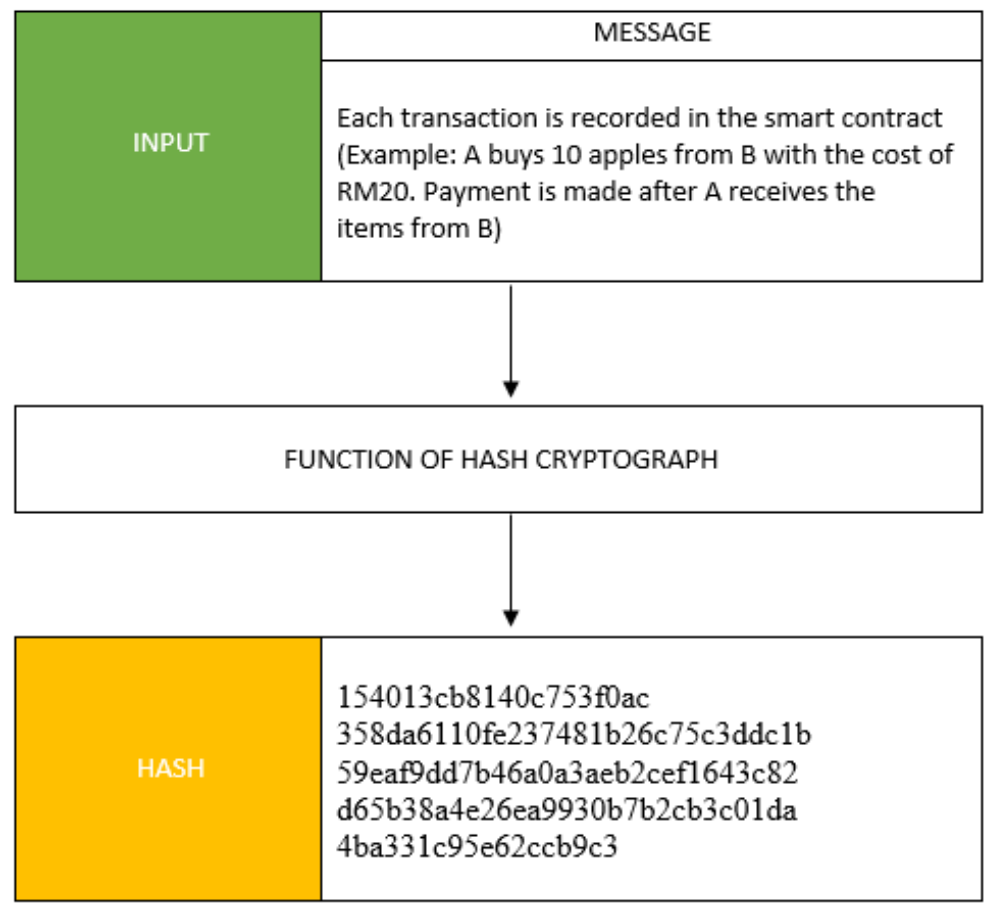

Source: Research Data

Each number is unique by itself as each block has a different hash number. Hash cryptography can be likened to a block's identity. Hash cryptography was introduced by Harber and Stornetta in 1991 by using the time-stamped document theory (Stancel, 2020). Hashing can change a text into values using mathematical theories. The aim of changing texts to values in blockchain is to compress the input message into a code. Hashing has the potential to tighten transmission security against any disruptions during the message delivery process to the recipient. Each hash recorded in the blockchain cannot be changed or deleted because the hash is bound by another hash number. In other words, the hash is a form of binding or a rope for tying each block in the network.

The hash cryptography method originated from Haber and Stornetta (1992) had introduced hash cryptography to improve the blockchain, which originated from the Merkle tree structure inspired by Ralph Merkle's binary tree. This concept is used as a basic component in blockchain technology for supporting the function of its application when efficiently and safely verifying big-structured data. Hash cryptography can take as much data as possible and summarise the data into one character so that it cannot be exposed to others, for example .ZIP or .RAR2 files. It also functions to bind each hash by combining each stored data so that it is difficult to make any changes to the data by irresponsible parties.

The Merkle tree was introduced by a computer scientist named Ralph Merkle through a conference paper entitled, 'A Digital Signature Based on a Conventional Encryption Function', which used the hash tree concept. The reason he introduced this concept was to hasten computer work that verified calculated data. Following is an illustration of the Merkle Tree. 


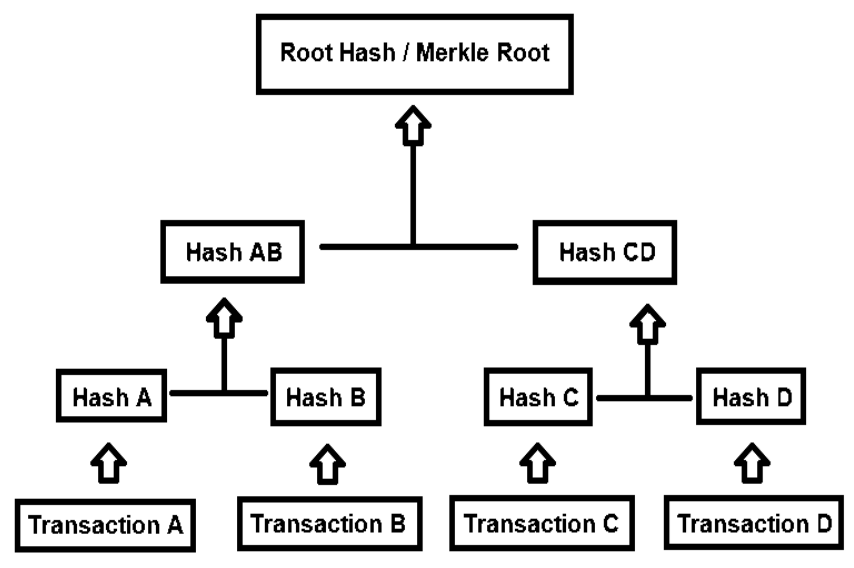

Source: hackernoon.com

Following are how transactions are bonded using hash until it forms the Merkle Tree. There are four transactions involved in the illustration, namely transactions $A, B, C$ and $D$, which refer to data stored in the transactions. Before a hash forms, data stored by the client or consumer is stored in a transaction ( $\mathrm{x}$ ). After a transaction is formed, the programmer begins operations to protect the transaction although the exterior of the transaction is visible, for example the contents of a present contract are visible even if it is wrapped. Therefore, hash cryptography functions to summarise data in a transaction to random numbers that start with four figures (0000) so that the data is not exposed to others. Then, hash cryptography is bonded together with other hash to become a chain, as depicted in the diagram above, until it forms the Merkle Tree. The intention is to ensure that the network of data in the Merkle Tree become immutable characters and each bonded data are inseparable among itself.

\section{Implementing the Smart Contract Using Blockchain}

In 2013, Buterin, V. demonstrated the capability of blockchain in expanding the Bitcoin protocol to smart contracts. Buterin showed that anyone can create a contract script in a blockchain using the Solidity computer language. Creating a smart contract in blockchain, as introduced by Buterin, is known as Ethereum. Ethereum has its own token called Ether, which acts as a substitute for Bitcoin. Buterin's study involved four levels that exist throughout the production of the Ethereum prototype, namely Frontie, Homestead, Metropolis and Serenity. Success of Ethereum led to the creation of peer-to-peer smart contracts in blockchain or also known as Decentralised Applications (Dapps). Dapps represents one perspective of the smart contract that is much wider when combined with the web user interface. The consumer can use Dapps to produce smart contracts through the web-fronted user interface application and peer-to-peer decentralised protocol storage. Each transaction with a smart contract code is recorded in the Ethereum blockchain using the Ethereum Virtual Machine (EVM).

Before entering into a smart contract, the consumer should have an Externally Owned Account (EOA) or better known as a wallet. Each owner of an EOA has a private key to access his/her own funds and contract. The EOA owner can make requests to send or transfer Ether transactions to another addresses. The Multisignature smart contract is applied into the Ethereum to verify the transaction carried out by the sender and the identity of the recipient. 
MANAGEMENT SCIENCES

Vol. 11, No. 3, 2021, E-ISSN: 2225-8329 @ 2021 HRMARS

The Solidity computer language is used in Ethereum to write each transaction in the smart contract. Each written contract contains the address, Ether delivery and receipt as well as the destination of the transaction. After the contract is translated into the Solidity computer language, the contract is sent to the Ethereum Virtual Machine (EVM) for verification, recording and storage in the blockchain by using hash cryptography.

SHARIAH-COMPLIANCE AS THE CORE ELEMENT IN BASIC ISLAMIC PRINCIPLES

The word "syariah" from a linguistic aspect originated from the Arabic word شَ meaning water that flows for drinking or farming purposes or a straight road (Laldin, M.A. 2006; Tarmizi, L. 2020). Syariah, in Islam, is the core element in a specific guideline related to life that has been distinctly and accurately arranged based on Islamic teachings. The fundamental aim of shariah has been mentioned in several verses of the al-Quran.

Meaning:

Now We have set you 'O Prophet' on the 'clear' Way of faith. So, follow it, and do not follow the desires of those who do not know' the truth.

(Quran, Al-Jasiyah 45:18) Islam has certain basic beliefs, which are the belief that Allah SWT is the ONLY God, Muhammad is the Prophet, the existence of the day of Judgement etc. (Abdul Rahman, 2012). These basic beliefs form the strength of faith (iman) that cannot be altered or separated from a Muslim in any circumstance. Islamic law or Syariah still upholds the basics but must follow the changes in times because human lifestyle is constantly evolving from time to time. Decrees and worship according to the Syariah should be referred and evaluated based on its suitability in a situation as long as it does not contradict Islamic aqidah (Saadan, 2000). These changes are permitted based on the term مَّنَ الََْمْْ in the verse above meaning 'based on this matter'. The uniqueness of Syariah includes all things good in a lifestyle, such as ethical values, worship, management and others (Al-Qaradawi, 1997). Syariah acts as a guide in life, which is integral and complete in terms of solving every problem faced by humans and also this world, in general. This shows that Islam is a comprehensive or complete religion. The decrees in Syariah are not only a form of worship towards the Creator but also aim to protect all aspects of life. The position of Syariah is guaranteed in the cycle of life as long as the bond is based on the al-Quran and Sunnah.

Moreover, it is undeniable that the financial industry plays an important role in society as well as from the Syariah compliant aspect. Islam, which is portrayed as a comprehensive (syumul) religion, emphasises on the decrees of Syariah related to commerce (muamalat) so that it is on the correct path. Thus, by instilling the element of Shariah-compliance in the financial sector, it tends to reduce the crime rate, in terms of usury (riba), gambling, fraud and so on. Islamic law applied in the economic sector has been practiced in the Malay States during the time when the Arab merchants began trading in Melaka. The propagation of Islamic law by the Arab merchants at that time was very effective and was eventually incorporated into the Law of Melaka (Zulkifli, 2008). Among the aspects of Syariah pertaining to the economic sector that was incorporated into the Law of Melaka was Article 30, which was regarding the prohibition of usury (riba) in business transactions.

In order to protect the core principles of Islam, each activity that uses the blockchain application needs to be Syariah compliant. The compliance ensures that blockchain technology is halal and safe for use by Muslims. By instilling confidence in blockchain technology as being halal, it needs to comply with maqasid al-shariah (Rabbani, Khan, \& 
MANAGEMENT SCIENCES

Vol. 11, No. 3, 2021, E-ISSN: 2225-8329 @ 2021 HRMARS

Thalassinos, 2020). Maqasid al-shariah plays a role in safeguarding the benefits accruing to an individual and society, including the prevention of detrimental elements prohibited in Islam. Maqasid al-shariah is also an essential key in the management of anything based on Syariah-compliance. It has the capability to protect Muslims from any wrong-doing that might occur. Following is a verse from the al-Quran pertaining to the objective of Syariah in everyday life. Allah SWT exhorted, meaning:

And We have not sent you, [O Muhammad], except as a mercy to the worlds.

(Al-Anbiya': 107).

In reference to the above verse, Laldin (2014) explained that it refers to the human characteristic of Allah SWT regarding humans based on the excerpt jَحَمَ or "rahmatan". The word refers to the decrees of Shariah established by Allah SWT in regard to human well-being and safety. It also refers to safeguarding human safety and preventing wrong-doings. Implementing the decrees of Syariah includes all aspects of life or the syumul perspective, such as crime, worship practices and commercial activities. Hence, maqasid al-shariah is a significant component that promotes a harmonious effect in every day activities. The knowledge surrounding maqasid al-shariah should not be suspect because it has been formed in a systematic and comprehensive manner by Imam as-Syathibi in his book al-Muwafaqat fi Usul as-Syari'ah.

Role of Maqasid Shariah In Blockchain Technology When Exercising Efforts to Deter The Spread of Covid-19

Maqasid originates from the word 'qasada', which means moving in a certain direction, whereas, syariah means 'source of water or road'. Shariah also means 'healer' based on the following verse in the al-Quran with the meaning:

O humanity! Indeed, there has come to you a warning from your Lord, a cure for what is in the hearts, a guide, and a mercy for the believers.

(Yunus: 57)

The role of Maqasid al-shariah is to act as an important measure in the protection of individual and societal benefits based on several critical characteristics, as mentioned below:

a. Jalb al-Masalih - achieve some significance in life

b. Dar al-Mafasid - reject potential destruction that will arise in society

c. Sadd al-Dharar - preventing or halting the main deleterious element

d. Taghayyur al-zaman - the 'prioritises change in time or era' factor

The critical characteristics mentioned above are used to measure the application of blockchain technology based maqasid syariah, especially in cases such as the preservation of life, religion, property, ethnic background or the human mind. Application of the blockchain technology during the Covid-19 pandemic in the type of cases mentioned above are based on the al-Quran and Sunnah in order to ensure it complies with the Syariah framework. Implementing blockchain technology could help achieve the importance of life, especially in the Islamic financial industry. Although discussions about blockchain technology is still being studied, it still has the potential to safely store data. Every human has the cognitive capacity to evaluate what is right and wrong. The human mind was created to question and abide by the creations and commands of Allah SWT, as exhorted by Allah SWT with the meaning:

And He is the One Who has dispersed you 'all' over the earth, and to Him you will 'all' be gathered. And He is the One Who gives life and causes death, and to Him belongs the alternation of the day and night. Will you not then understand? 
The verse above explains that the human mind is meant to evaluate and discern all the truth bestowed by Allah SWT. The verse also explains that the mind can eliminate doubtful thinking that leads to the disbelief of Allah SWT. Hence, the qawaid fiqiyyah principle states that confidence cannot be defied by doubt depending on the knowledge learned by the mind. The confidence must be supported by decrees and teachings that are guided by worshiping Allah SWT. For example, when a person is confident that he has performed ablution but is doubtful whether it is still valid; hence, he does not have to perform ablution again because he is confident that he has performed ablution, whereas the validity of the ablution is only a doubt.

When science and technology are associated with this method, a person must be confident in the knowledge he possesses and the capability of making decisions that comply with Islamic Syariah. This is because knowledge about science and technology is innovated according to changes in time and it is established based on clear decrees found in the al-Quran and Sunnah. However, if there are contradictions with a decree, guidelines about establishing a decree requires accurate knowledge that must be subjected to qiyas and be Shariah-compliant. Thus, if there is doubt about something that impedes Islamic progress, then, that matter must be avoided. Each innovation in science and technology needs to be measured and fulfil the objectives of maqasid al-shariah. Following is an analysis of implementing blockchain technology during the Covid-19 pandemic based on achieving the objectives of maqasid alshariah.

\section{a. Protection of Property}

The use of blockchain is presumed to be an innovation in the Islamic financial technology sector. Choosing to implement blockchain technology in this industry can help develop the direction of virtual businesses. At the same time, the use of this technology is a heated topic at the national level and has paved opportunities for technological advancements in Islamic finances in Malaysia. Its implementation to help blockchain products was first introduced in the halal industry and Islamic financial system (Farah, 2018). Protecting and preserving property is another element that warrants attention. Each person owns property that has been obtained from halal sources. Islam forbids its subjects from transgressing or usurping others' property without firm reasons or a valid contract. The following verse mentions about the prohibition of usurping another person's property.

Meaning:

And [for] their taking of usury while they had been forbidden from it, and their consuming of the people's wealth unjustly. And We have prepared for the disbelievers among them a painful punishment.

(An-Nisa': 161)

Since there are movement restrictions involving the economic sector during the Covid-19 pandemic, consumers can carry out any sort of online business in a transparent and safe manner in order to return stability to the Malaysian economic sector. Each transaction in a smart contract that is bonded using blockchain is guaranteed its safety because it is difficult to change or delete. However, if it still occurs, the bonded block can detect the changes.

Any transfer concerning transactions, including sales and purchase transactions and others related to data storage, can be carried out using the Ethereum smart contract. The parties involved can implement the contract without any face-to-face interaction between 
MANAGEMENT SCIENCES

Vol. 11, No. 3, 2021, E-ISSN: 2225-8329 @ 2021 HRMARS

them. Implementing an Ethereum smart contract is similar to the e-commerce concept, for example Shoppee, Lazada, Amazon etc. One difference between an Ethereum smart contract and e-commerce is that the contract implemented in a blockchain can be implemented in the long-term and is binding. In addition, data stored in the blockchain is safe and cannot be altered after it is bound with another hash number. Below is an illustration of a smart contract that has been designed in the Solidity Programming Language:

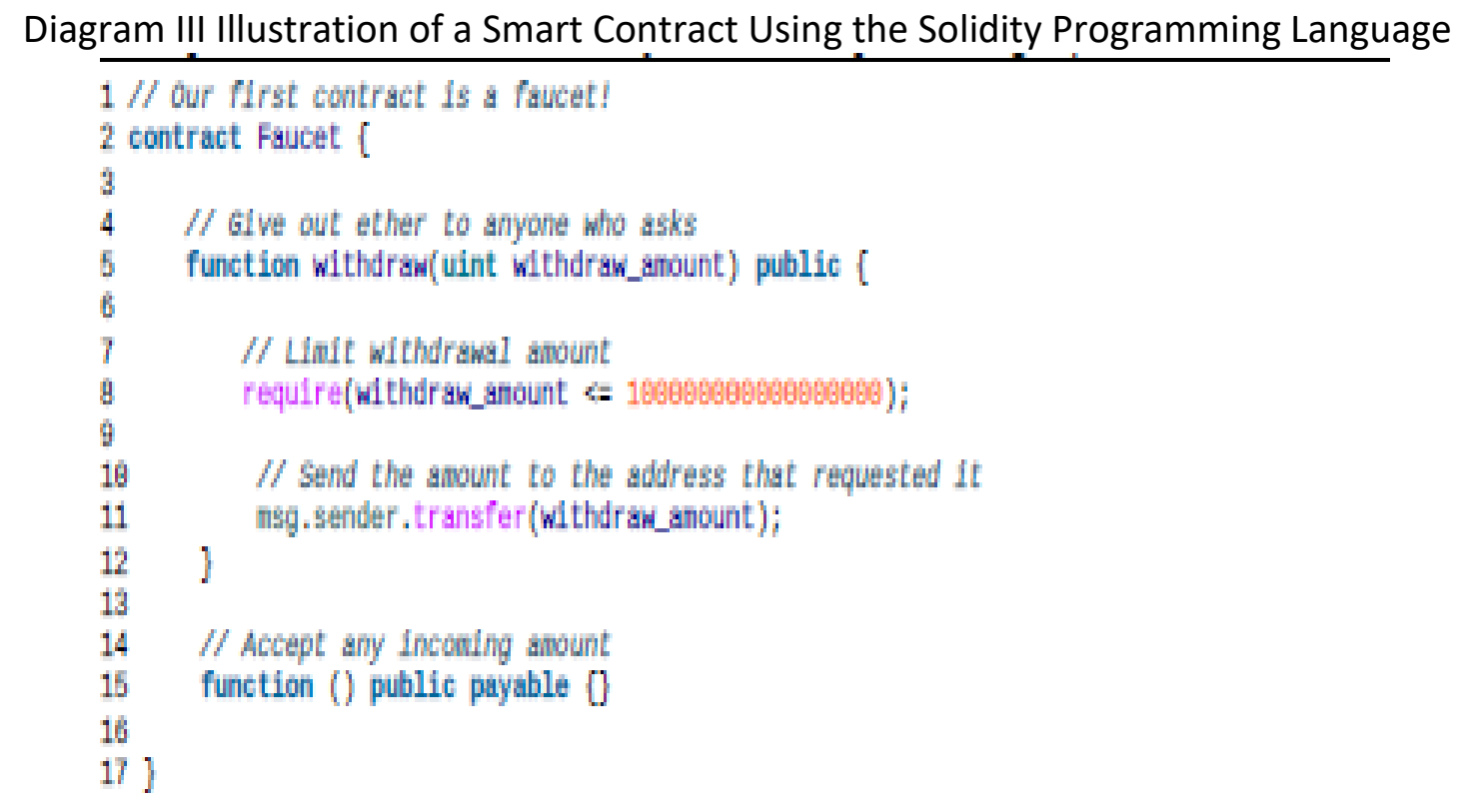

Source: Mastering Ethereum Building Smart Contracts and Dapps (2019)

Above is an illustration of the Ethereum smart contract concerning an agreement between two parties regarding a Ether crypto transfer transaction. The second row shows the beginning of the contract, which states the declaration of the contract using the $(\{)$ code. The $5^{\text {th }}$ row depicts the first function of the contract, which is called withdraw. The party responsible is yet to be certified and has not put down the signature based on the code (unit). The 'public' code means the declaration of a public function that calls for a new contract. The fifth row depicts a bargaining process between two parties. The eighth row depicts the first part of establishing the production limit function. The total production should not exceed ( $<=)$ the amount agreed upon. Thus, if the production is more than the established amount, then the contract is automatically terminated. The eleventh row depicts a transaction by another party. After the parties have agreed to the amount mentioned then the parties can continue with the contract. The 'msg' code refers to input that can be accessed by all contracts and represents transactions that trigger the implementation of a contract. The 'transfer' contract refers to the transfer of the Ether to the recipient. The illustration (of the contract) shows that each transaction is recorded in order to facilitate the monitoring of activities and verification of the agreement between them. The contract is then collected and recorded in the blockchain using the Ethereum Virtual Machine (EVM).

\section{b. Preservation of Life}

Curbing the spread of the Covid-19 pandemic in Malaysia has been a challenge for the government, who had initiated various measures; one being to restrict social distancing among people in public. The number of active Covid-19 cases as of 5 June 2021 was 85,607, 
MANAGEMENT SCIENCES

Vol. 11, No. 3, 2021, E-ISSN: 2225-8329 @ 2021 HRMARS

with 3,291 recorded deaths. The spread of this pandemic has made it difficult for society to carry out their daily activities in the economic sector. Social distancing was intended to reduce the spread of the Covid-a9 pandemic and the preservation of human life, which is a principle that involves the protection of dignity, equality, social values, justice, spirituality, morality, security, freedom, respect etc.. Life is precious commodity to every human being regardless of one's religious status, ethnic background or financial status. In order to preserve life, Allah SWT has established obligatory hudud law that serves as a deterrence to humans whose actions are detrimental to human life, as mentioned in the Quran.

Meaning:

O you who have believed, prescribed for you is legal retribution for those murdered - the free for the free, the slave for the slave, and the female for the female. ${ }^{1}$ But whoever overlooks from his brother [i.e., the killer] anything, ${ }^{2}$ then there should be a suitable follow-up and payment to him [i.e., the deceased's heir or legal representative] with good conduct. This is an alleviation from your Lord and a mercy. But whoever transgresses after that ${ }^{3}$ will have a painful punishment.

(Al-Baqarah: 178)

The decree serves justice to the family of the deceased as well as a lesson to Muslims so as not to cause death amongst humans. It is also intended to instil harmony and love amongst humans in a peaceful manner. Based on the preservation of life context, blockchain is the best choice to uphold the preservation of life principle as well as stimulate progress in the economic sector. Blockchain is capable of becoming a communication platform in the economic sector by using the Distributed Ledger Technology (DLT) network. Use of blockchain in the business sector can reduce face-to-face meetings and maintain the social distancing protocol established by the government.

(Marbouh, et al., 2020) are of the view that blockchain can fight Covid-19. Blockchain has the potential to control, monitor and ensure that the product supply chain is always stable and sufficient. All recorded data can be shared with other parties without concern of whether the data would be altered by irresponsible parties. In addition, blockchain allows savings in costs otherwise accruing to intermediaries involved in a manually processed contract. Blockchain technology is not only used in the economic sector but it can also enhance the healthcare sector that is affected by the pandemic in various aspects, including improving clinical tests, managing supply chain operations, monitoring donations etc.

Financial resources are critical in the health sector throughout the Covid-19 pandemic mainly for purchasing medical supplies, such as Personal Protection Equipment (PPE). Expenditure on medical necessities is also crucial as it makes verification of prices, quality as well as the originality of technology and equipment very challenging (Aarvik, 2020). Blockchain technology is capable of overcoming these problems. It can be used to manage medical supply chains by ensuring quality and originality of medical equipment based on data records that have been securely maintained. Each data concerning a medical record placed in the blockchain cannot be changed or decrypted and it is a application for tracking Covid-19 data.

\section{Conclusion}

This study found that blockchain technology can be suitably used in any form of transaction throughout the Covid-19 pandemic. This technology has the potential to become a data storage application for the Covid-19 medical supply chain and control of the medical equipment expenditure budget. It not only protects the property of contracting parties but it also offers other benefits, such as the protection of lives from Covid-19 infections. 
MANAGEMENT SCIENCES

Vol. 11, No. 3, 2021, E-ISSN: 2225-8329 @ 2021 HRMARS

Nevertheless, applying blockchain technology in any activity is not easy. Studies on the input and concept of blockchain technology should be carried out to ensure the application is safe and guaranteed by certified parties. Besides that, implementing products related to blockchain, namely cryptocurrency, is still at the initial stages of determining whether it is Syariah compliant.

\section{References}

Kadir, A. J. (2020). Kesan Covid-19 Kepada Ekonomi. Sinar Harian. September 2020. https://www.sinarharian.com.my/article/99861/KOLUMNIS/Kesan-Covid-19kepada-ekonomi.

Aarvik., P. (2020). Blockchain Technology to Prevent Corruption in Covid-19 Respons: How Can It Help Overcome Risks? https://www.cmi.no/publications/7259blockchain- technology-to-prevent-corruption-in-covid-19-response-how-canit-help-overcome-risks

Abdul Rahman, N. (2012). Pemahaman Konsep Tauhid Asas Keharmonian Kepelbagaian Agama. International Journal of Islamic Thought, 34-42.

Abouzid, N. H. (2020). From Covid-19 Pandemic to A Global Platform Relies on Blockchain to Manage International Trade, Why Not? Mesir.

https://www.unescap.org/sites/default/files/176\%20FinalTeam\%20Hala\%20NasrEgypt.pdf

Al-Qaradawi, Y. (1997). Shari'ah Al-Islam Salihah Lil Al-Tatbiq Fi Kull Zaman Wa Makan. Kaherah: Maktabah Wahbah.

Amir, A. H. (2021). Majikan Ingkar SOP BDR Bakal Dikenakan Tindakan. Mei 2021. https://www.hmetro.com.my/mutakhir/2021/05/711182/majikan-ingkar-sop-bdrbakal-dikenakan-tindakan-metrotv

Anon. (2020). Covid-19: Syarikat Mula Sedar Kepentingan Transformasi Digital. Jun 2020. https://www.sinarharian.com.my/article/99861/KOLUMNIS/Kesan-Covid-19-kepadaekonomi

Antonopoulos, A. M., \& Wood, G. (2019). Mastering Ethereum: Building Smart Contracts and DAPPS. Sebastopol: O'Reilly Media.

Bashah, N. I. (2017). Antara Teknologi dan Maqasid Shariah. Utusan. Mac 2019. http://irep.iium.edu.my/69622/1/69622_Matawang\%20Digital\%20$\% 20$ Antara\%20teknologi.pdf

Farah, A. (2018). Pasukan Petugas Khas Tumpu Pelaksanan Blockchain. Berita Harian. Mac 1. https://www.bharian.com.my/bisnes/lain-lain/2018/03/394518/pasukanpetugas-khas-tumpu-pelaksanaan-blockchain

Jabatan Kemajuan Islam Malaysia. (2015). Indeks Syariah Malaysia: Model Tadbir Urus Berteraskan Maqasid Syariah.

Lahiri, P. K., Mandal, R., Banerjee, S., \& Biswas, U. (2021). An Approach Towards Developments of Smart COVID-19 Patient's Management and Triaging Using Blockchain Framework. Nadia: Research Square.

Laldin, M. (2006). Introduction to Shari'ah and Islamic Jurisprudence (3rd ed.). Kuala Lumpur: Perpustakaan Negara Malaysia.

Marbouh, D., Abbasi, T., Maasmi, F., Omar, I. A., et al. (2020). Blockchain for COVID-19: Review, Opportunities, and a Trusted Tracking System. Nature Public Health Emergency Collection, 1-17. doi:10.1007/s13369-020-04950-4 
Rabbani, M. R., Khan, S., \& Thalassinos, E. I. (2020). FinTech, Blockchain and Islamic Finance: An Extensive Literature Review. International Journal of Economics and Business Administration, VIII(2), 65-86. doi:10.35808/ijeba/444

Saadan, M. (2000). Fiqh Semasa: Konsep dan Aplikasinya. Universiti Malaya. https://www.jais.gov.my/userfiles/user/Artikel/ARTIKEL_FIQH_SEMASA.pdf

Shahir, A. (2020). Implikasi Covid-19 Kepada Ekonomi Negara. Malaysia Kini. June 20. https://www.malaysiakini.com/news/531780

Stancel, D. (2020). Coin Perspective\#11 - Stuart Harber. 1 September. https://medium.com/coin-story/coin-perspective-11-stuart-haber-d1445257dc98

Tarmizi, L. (2019). Irsyad Usul-Fiqh Siri ke-33: Pendahuluan Kepada Ilmu Maqasid Syariah. Pejabat Mufti Wilayah Persekutuan. Kuala Lumpur. 8 September.

Yusainy, M. (2021). PKP 1.0 Memberi Kesan Negatif Kepada Ekonomi Negara. Sinar Harian. Mei 19.

https://www.sinarharian.com.my/article/139422/BERITA/Nasional/PKP-10-berikesan-negatif-kepada-ekonomi-negara-AMCHAM.

Zulkifli, H. (2008). Sejarah Undang-Undang Keterangan Islam Di Malaysia. Universiti Sains Islam Malaysia. https://zulkiflihasan.files.wordpress.com/2008/05/sejarahundang-undang-keterangan-islam-di-malaysia-isi-kandungan1.pdf 